\title{
The effective practices of mobile phone producers' green supply chain management in reducing GHG emissions
}

\author{
Yazan Khalid Abed-Allah Migdadi
}

Department of Management and Marketing, College of Business and Economics, Qatar

University, Doha, Qatar

\section{Correspondence}

Yazan Khalid Abed-Allah Migdadi, Management and Marketing Department, College of Business and Economics, Qatar University, P.O. Box 2713, Doha, Qatar.

Email:ymigdadi@qu.edu.qa

\begin{abstract}
The aim of this study is to identify management practices that effectively reduce greenhouse gas (GHG) emissions with regard to the green supply chain adopted by mobile phone producers. Six cases were surveyed (Apple, Samsung, LG, Huawei, Nokia, and ZTE). The main source of data was sustainability reports, which were retrieved from the Global Reporting Initiative database. A special data analysis technique called rank analysis was adopted. The results revealed that the effective practices to reduce GHG 1 emissions were related to production process and business travel; those that were effective for reducing GHG 2 emissions were related to facilities accreditation and energy saving; and those effective in reducing GHG 3 emissions were related to logistics and customer practices. No effective actions related to the management of relationships with suppliers were identified by this study. Indicative models for the relationship between actions and GHG emissions were developed, as was a value-stream map. The previous studies reporting the effective practices in other industries reported results for reducing GHG 1 or GHG 3, or overall GHG emissions, without discriminating among the actions taken to reduce such emissions, although some limited actions were reported. This study describes the effective practices along the whole supply chain-both upstream and downstream-and it also lists the actions related to addressing all the emissions, whether GHG 1, 2, or 3.
\end{abstract}

KEYWORDS

effective practices, GHG emissions, green, mobile phone, supply chain

\section{1 | INTRODUCTION}

The Paris Agreement adopted in 2015 set the specific intentions of holding global warming to well below 2 degrees Celsius $\left({ }^{\circ} \mathrm{C}\right)$ under preindustrial levels, and of trying to limit warming to $1.5^{\circ} \mathrm{C}$. The successful Paris Agreement has generated and incentivized action on the appropriate scale by both governments and the private sector. Global greenhouse gas (GHG) emissions in $\mathbf{2 0 2 0}$ are likely to be at the high end of the acceptable range of these targets. This increases the challenge of meeting the necessary 2030 emission goals. Accordingly, more effort should be made to reduce GHG emissions as recommended by the Paris Agreement (United Nations [UN] Environment, 2017).

The Information and Communication Industry (ICT) has received little attention as a significant contributor to GHG emissions, despite the increase in its contribution from $1 \%$ to $1.6 \%$ of the worldwide GHG emissions in 2007, rising to $14 \%$ in 2016. By 2040, it will exceed this figure. The carbon footprint of smartphones alone will outstrip the individual contribution of desktops, laptops, and displays by 2020 (Belkhir \& Elmeligi, 2018). Smartphones represent a fast-growing segment of
ICT (Wilson, 2018). About 1.9 billion of them were sold in 2017, and the number is expected to reach 6.1 billion by 2020 , enough for $70 \%$ of the global population (Jardim, 2017).

The use phase of smartphones has become increasingly energy efficient over the years, which has helped to reduce GHG emissions, but the manufacturing phase remains hopelessly reliant on fossil fuels. The entire lifecycle of the iPhone $6 \mathrm{~s}$ emitted about $95 \mathrm{~kg}$ of $\mathrm{CO}_{2}, 85 \%$ of which occurred in the manufacturing stage (Suckling \& Lee, 2015). The projected sales of 80 million of the iPhone $6 \mathrm{~s}$ are expected to generate a total annual carbon footprint of 6,460 kilotons of $\mathrm{CO}_{2}$, which is greater than the emissions of 770,000 people and all the business of the London boroughs of Westminster, Lambeth, and Camden put together (Good Electronics, 2015). In addition, building an iPhone 7 Plus creates roughly $10 \%$ more $\mathrm{CO}_{2}$ emissions than an iPhone 6 s does (Wilson, 2018). 
producers (e.g., Huang, Wang, Zhang, \& Pang, 2016), electronics in general (e.g., Belkhir \& Elmeligi, 2018; Hsu, Kuo, Chen, \& Hu, 2013), and the chemical industry (Zhang, Shah, Wassick, Helling, \& Van Egerschot, 2014). Few studies have investigated the environmental impact of producing mobile phones (e.g., Migdadi, 2015, 2016; Suckling \& Lee, 2015; Belkhir \& Elmeligi, 2018). The later study by Migdadi (2016) reported the best practices of the green operations strategy, but the focus of this study was found to be too broad in terms of green indicators. The best practices were found to be related to waste management and recycling. This study did not examine in depth the impact of green actions in GHG emissions, and it did not discriminate between the scope of different GHG emissions (1, 2, and 3). The earlier study by Migdadi (2015) reported the design of effective green base stations, so green actions of the mobile phone producers were beyond its scope. Another study by Belkhir and Elmeligi (2018) evaluates and forecasts the carbon footprint of the electronic sector in general with some focus in mobile phone producers in particular and projects the impact by 2040 . The study by Suckling and Lee (2015) evaluates the environmental impact of smartphones. The last two studies do not investigate what actions are effective in reducing GHG emissions.

\section{No clear investigation of the impact of actions related to each scope of GHG emissions has been included in one study.}

Most previous studies have focused in reporting on particular processes, and a limited number of actions in supply chain management. No clear investigation of the impact of actions related to each scope of GHG emissions has been included in one study. Most studies have investigated limited or one scope's action, such as GHG 1 or GHG 3 actions. Accordingly, this study will bridge these research gaps by investigating the whole process of the green supply chain in the mobile phone industry and will discuss all the effective actions adopted, without any preidentified limits. It will also describe the impact of the actions with regard to each scope of GHG, and distinguish one scope from another. To this end, the following objectives were attained:

1. Reporting the change in each scope of $G H G$ emissions $(1,2$, or 3$)$ of the mobile phone producers industry over the previous year (2017).

2. Identifying the green supply chain management actions taken in each case to reduce each scope of GHG emissions (1, 2, and 3) over the previous year (2017).

3. Developing indicative models for the relationship between the significant actions taken and the degree of reduction in each scope of GHG emissions (scopes 1, 2, and 3).
4. Developing the value-stream map for effective green supply chain management in reducing the GHG emissions of mobile phone production.

This paper is structured in five sections: The first is the literature review, which gives rise to the conceptual model of the study. The second section describes the research methodology and data analysis techniques used in the study. The third contains the data analysis and findings. The fourth section discusses these. The last section presents the conclusions of the paper, its applications and limitations, and some suggestions for future research.

\section{2 | LITERATURE REVIEW}

The performance indicators in practicing green operations can be classified into financial, operational, and environmental. The financial indicators show the cost saved as a result of saving energy and material. The operational indicators show a better use of capacity, improved productivity, and a smaller inventory. The environmental indicators show the reduction of GHG emissions, solid waste, and energy consumed (Guang Shi, Lenny Koh, Baldwin, \& Cucchiella, 2012; Zhang \& Yang, 2016). Therefore, GHG emissions are one of the environmental performance indicators.

Six gases can be classified as GHG emissions-carbon dioxide $\left(\mathrm{CO}_{2}\right)$, methane $\left(\mathrm{CH}_{4}\right)$, nitrous oxide $\left(\mathrm{N}_{2} \mathrm{O}\right)$, hydrofluorocarbons (HFCs), perfluorocarbons (PFCs), and sulfur hexafluoride $\left(\mathrm{SF}_{6}\right)$. Data for all of them may be reported separately in metric tons or as equivalent tons of $\mathrm{CO}_{2}$. Most corporations report $\mathrm{GHG}$ emissions as $\mathrm{CO}_{2}$ metric tons or as $\mathrm{CO}_{2}$ equivalent. $\mathrm{GHG}$ emissions can be classified as direct or indirect; the first kind, which is classified as direct emissions, is called GHG 1 (scope 1), meaning direct GHG emissions from sources that are owned or controlled by the company; for example, emissions from combustion in a company's owned or controlled boilers, furnaces, vehicles, etc. Indirect GHG emissions can be classified into GHG 2 (scope 2) and GHG 3 (scope 3). GHG 2 is the name given to indirect GHG emissions from the direct billing of electricity in a company's owned or leased facilities under the control of the corporation. GHG 3 emissions are the remaining indirect emissions-not the GHG 2 emissions from a company's activities, but emissions produced by sources not owned or controlled by the company. Some examples of scope 3 activities are the extraction and production of purchased materials, transportation of purchased fuels, and use of sold products and services (World Business Council for Sustainable Development and World Resources Institute, 2017).

Not many studies have reported all types of GHG emissions in detail. Most studies have reported GHG 1 (Bazan, Jaber, \& Zanoni, 2015; Jaber, Glock, \& El Saadany, 2013) or GHG 3 (Blanco, Caro, \& Corbett, 2016; Elhedhli, \& Merrick, 2012; Haddadsisakht \& Ryan, 2018) or both, without differentiating between GHG indicators (e.g., Coskun, Ozgur, Polat, \& Gungor, 2016; Egilmez et al., 2014; Huang et al., 2016; Nakamichi et al., 2016; Zhang et al., 2014). As for GHG 2 emissions, most previous studies have not given clear accounts of them. 
According to the life-cycle assessment process, all organizations should investigate the environmental impact of their operations over all aspects of their operational processes, products, and materials (Bjørn \& Hauschild, 2013; Boehme, Panero, Muñoz, Powers, \& Valle, 2009; de Bakker, 2001; Joshi, 1999; Matthews \& Small, 2000; Migdadi \& Elzzqaibeh, 2018; Migdadi \& Omari, 2019), so that $\mathrm{CO}_{2}$ emissions should be reported for suppliers' practices, logistics processes, business travel, manufacturing, customers' practices, and the operation of offices and facilities.

Previous studies of GHG emissions related to green supply chain practices have focused on examining a few green actions. The surveyed actions in supplier relationship management were the number of different components supplied (Huang et al., 2016) and the number of suppliers (Blanco et al., 2016). The actions in the order fulfillment process (manufacturing) that were surveyed were the location of manufacturers (Nakamichi et al., 2016), the modules of the product line (Huang et al., 2016), manufacturer production rates (Bazan et al., 2015), the capacity of production processes (Azadeh, Raoofi, \& Zarrin, 2015; Zhang et al., 2014), processing time (Zhang et al., 2014), and the number of facilities opened (Haddadsisakht \& Ryan, 2018).

Logistics management actions were related to the locations of suppliers (Nakamichi et al., 2016), the length of the transportation routes (Azadeh et al., 2015; Elhedhli \& Merrick, 2012; Nakamichi et al., 2016) or the distances between suppliers, manufacturers, and customers (Huang et al., 2016; Zhang et al., 2014), the mode of transportation and number of vehicles (Haddadsisakht \& Ryan, 2018; Huang et al., 2016; Nakamichi et al., 2016), the number of shipments in a manufacturer's cycle (Bazan et al., 2015), and the capacity of distribution centers (Elhedhli \& Merrick, 2012; Jaber et al., 2013). Actions in managing the customer relationship were the size of customer demand (Azadeh et al., 2015; Huang et al., 2016) or the size of customer orders (Zhang et al., 2014).

The studies of logistics, transportation, and distribution management revealed that in the automobile industry, maritime transportation generates a huge amount of emissions, resulting from the space occupied by cargoes of cars (Nakamichi et al., 2016). A more environmentally friendly transportation mode is employed for the lowvalue components of air-conditioner products (Huang et al., 2016). The cost of setup and holding and, consequently, of emissions, can be reduced if trucks with larger capacities are used and not transferred empty (Bazan et al., 2015). One study finds that the rate of carbon tax decreases by increasing the use of transportation (more capacity and lower carbon emissions per item) (Haddadsisakht \& Ryan, 2018). The addition of a carbon tax reduces travel (fewer vehicle kilometers) and thereby reduces transportation cost and opens more distribution centers to satisfy customer demand (Elhedhli \& Merrick, 2012)

H1: The more capacity use of the logistics transportation mode, the lower the GHG 3 emissions of the supply chain.

$\mathrm{H} 2$ : The shorter the transportation distance, the lower the GHG 3 emissions of the supply chain.
Studies of production processes reveal that the indirect $\mathrm{CO}_{2}$ emissions of the production processes depend on the local electrical resources (Nakamichi et al., 2016). The average onsite carbon footprint of the food industry is about $9.2 \%$, and the average supply chain carbon footprint is about $90.8 \%$ (Egilmez et al., 2014). Obtaining equipment requiring lower idle energy during standby and sleeping mode until the next production cycle commences will speed up the production process, as manufacturers would no longer need to shut down the equipment to avoid expending excessive energy on idling. Such equipment is particularly necessary if the facility produces more than one product, as it reduces the setup time for each production batch (Bazan et al., 2015).

H3: Equipment with more energy-saving devices will reduce the GHG 1 emissions of the supply chain.

Studies of supplier relationship management reveal that the greater the pressure to reduce $\mathrm{CO}_{2}$ emissions in the manufacture of air conditioners, the stronger the incentive to choose closer suppliers without consideration of the best deals financially, which often increases the price of products (Huang et al., 2016). Firms with many suppliers capture a significant portion of the GHG 3 emissions in their supply chains (Blanco et al., 2016). The significant actions were related to inventory level, which affects the production cost and the GHG emissions (Jaber et al., 2013). The training of suppliers and the availability of management systems of carbon information for suppliers were the two significant determinants in selecting suppliers (Hsu et al., 2013).

H4: Choosing closer suppliers will reduce the GHG 3 emissions of the supply chain.

H5: The lower the number of suppliers, the lower the GHG 3 emissions of the supply chain.

H6: Training suppliers to reduce carbon emissions will reduce the GHG 3 emissions of the supply chain.

H7: The availability of a management system of carbon information for suppliers will reduce the GHG 3 emissions of the supply chain.

Studies of customer relationship management reveal that the industries considered closer to their customers account more often for lower GHG 3 emissions than do upstream suppliers, who are closer to these industries (Blanco et al., 2016). According to Coskun et al. (2016), customers are classed in different segments according to their "green" expectations: greener, inconsistent, and red. The retailer will redesign the supply chain according to customers' green requirements. If more greening is required, the retailer will ask the supplier to tailor his requirements to satisfy the greening requirements. Customers in different segments may react differently to price increases as a result of greening requirements: inconsistent customers are less willing to pay for more greening; hence, suppliers and retailers serving these customers should pay more attention to reducing the cost of their inputs.

H8: The more "green" the customers' requirements, the lower the GHG 3 emissions of the supply chain. 


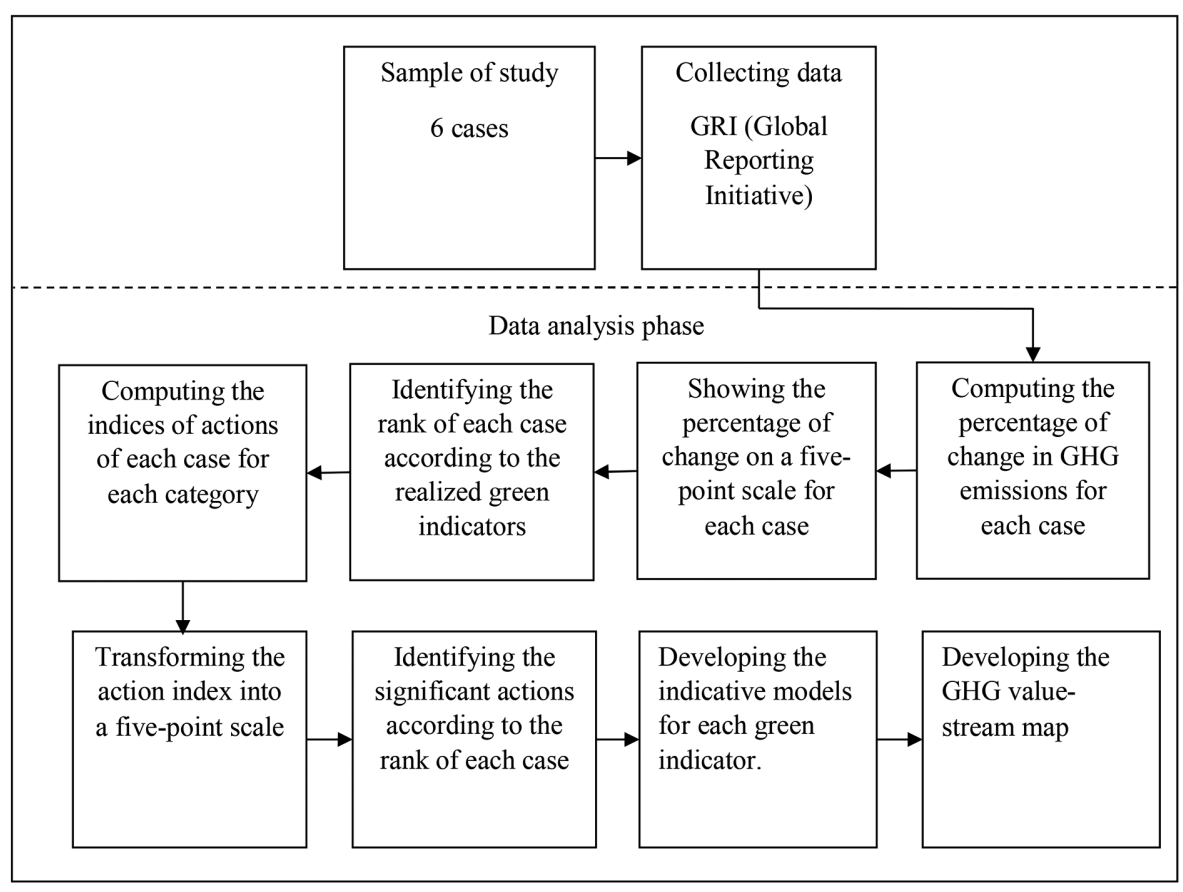

EXHIBIT 1 Flowchart of the research methodology

EXHIBIT 2 Study sample's market share

\begin{tabular}{ll} 
Corporations & $\begin{array}{l}\text { Market share } \\
\text { (StatCounter, 2018) }\end{array}$ \\
\hline Samsung & $30.8 \%$ \\
\hline Apple & $20.66 \%$ \\
\hline Huawei & $7.57 \%$ \\
\hline LG & $3.11 \%$ \\
\hline Nokia & $1.24 \%$ \\
\hline ZTE & $0.57 \%$ \\
\hline Total market share & $63.95 \%$ \\
\hline
\end{tabular}

\section{3 | RESEARCH METHODOLOGY AND METHODS}

The figure in Exhibit 1 shows the process flowchart of the present research methodology. It can be seen that this methodology passed through different phases: the first phase was to identify the study sample, followed by collecting the required data, and the last phase was data analysis. The data analysis phase involved eight steps, from computing the percentage of change in the green indicators for each case to developing the value-stream map. The following sections explain in more detail the phases and steps of the research methodology.

\section{1 | The study sample}

The sample used in the present study was a convenience sample determined by the availability of secondary published data. The sample concerned the green actions reported by corporations and the green indicators in their sustainability reports; however, the sample used in this study is also representative of the industry, as it covers more than $60 \%$ of the market share (see the table in Exhibit 2).
EXHIBIT 3 Definitions of the GHG indicators as reported by the corporations

\begin{tabular}{|c|c|}
\hline $\begin{array}{l}\text { GHG } \\
\text { indicator }\end{array}$ & Definition \\
\hline GHG 1 & $\begin{array}{l}\text { Million metric tons of direct carbon dioxide equivalent for } \\
\text { the energy used in the facilities owned and controlled by } \\
\text { the corporations. }\end{array}$ \\
\hline GHG 2 & $\begin{array}{l}\text { Million metric tons of indirect carbon dioxide equivalent } \\
\text { for the electricity purchased from a utility provider for } \\
\text { the facilities owned or controlled by the corporations. }\end{array}$ \\
\hline GHG 3 & $\begin{array}{l}\text { Million metric tons of indirect carbon dioxide equivalent } \\
\text { of upstream and downstream activities out of the } \\
\text { corporation ownership or direct control, such as } \\
\text { logistics, suppliers' activity, and customer use. }\end{array}$ \\
\hline
\end{tabular}

\section{2 | Data collection}

The data were all derived from published sustainability reports. The reports were retrieved from the Global Reporting Initiative (GRI) database. The GRI is an independent international organization established in the United States in 1997. It seeks to help organizations to report their impact on sustainability. It develops standards for reporting sustainability and publishes reports via its website (GRI, 2018). The data collected were related to green indicators (namely, GHG 1, GHG 2, and GHG 3) over the recent year (2017) and the actions taken for each case. The table in Exhibit 3 shows the definition of GHG indicators. To find out more about the actions of green supply chain management of this study, see Section 4.2.

\subsection{Data analysis phase}

The form of data analysis that we adopted is called rank analysis, as the cases were ranked according to the degree shown on the green indicators. The following detailed procedure was followed for this purpose: 
3

\section{$\mathbf{L}$}

L
M
4
5

EL H EH

(a) Improved green performance scale

0

1 2
3
4
5

EL

$\mathbf{L}$

M

H

EH

(b) Deteriorated green performance scale

$$
\text { Notes: } \mathbf{E L}=\text { Extremely Low } \quad \mathbf{L}=\text { Low } \quad \mathbf{M}=\text { Moderate } \quad \mathbf{H}=\text { High } \quad \mathbf{E H}=\text { Extremely High }
$$

EXHIBIT 4 Rating scale of green performance [Color figure can be viewed at wileyonlinelibrary.com]

Step 1: Computing the percentage of change in the green indicators for each case. In this study, three indicators were reported: GHG 1, GHG 2, and GHG 3. The following formula was used for this purpose:

$$
\begin{aligned}
& \% \text { of change in green indicator } \\
& \quad=\left[\left(P_{2017}-P_{2016}\right) / P_{2016}\right] \times 100 \%
\end{aligned}
$$

Step 2: Showing the percentage of change on a five-point scale for each case, as presented in the figure in Exhibit 4. Two scales were adopted: one (called the improved green performance scale) if the performance had improved, and the other one (called the deteriorated green performance scale) if the performance had deteriorated. In the case of GHG 1 , GHG 2, or GHG 3, an improved performance means a reduction in emissions, for example $-26 \%$. Conversely, a poorer performance means an increase in emissions, for example $+12 \%$.

The rating score was developed by using the benchmarking technique. In this technique, the best improved performance score was identified and used to create a benchmark for the purpose of comparison. Then, the percentage registered in each case was divided by the best score when the performance was improved, or divided by the worst score when the performance had deteriorated, and then multiplied by 5 . The following formula summarizes this. The table in Exhibit 5 shows an illustrative example.

$$
\begin{aligned}
& \text { (performance of case }(\mathrm{A})) /(\text { best performance score) } \\
& \times 5 \text { improved performance } \\
& \text { (performance of case }(\mathrm{A})) /(\text { worst performance score) } \\
& \times 5 \text { deteriorated performance }
\end{aligned}
$$

Step 3: Identifying the ranking of each case according to the green

\begin{tabular}{|c|c|c|c|c|}
\hline \multicolumn{5}{|c|}{ GHG1 } \\
\hline Case & $\%$ & Scaled on 5 points & Level & Rank \\
\hline Nokia & $-24 \%$ & $-24 \% /-24 \%=1 \times 5=5$ & $\mathrm{EH}$ & 1 \\
\hline Apple & $-7 \%$ & $\begin{aligned}-7 \% /-24 \% & =0.29 \times 5 \\
& =1.46\end{aligned}$ & $\mathrm{~L}$ & 2 \\
\hline Huawei & $-5 \%$ & $\begin{aligned}-5 \% /-24 \% & =0.21 \times 5 \\
& =1.04\end{aligned}$ & $\mathrm{~L}$ & 2 \\
\hline ZTE & $-4.7 \%$ & $\begin{aligned}-4.7 \% /-24 \% & =0.20 \times 5 \\
& =0.94\end{aligned}$ & EL & 3 \\
\hline Samsung & $20 \%$ & $\begin{aligned} 20 \% / 24 \% & =0.83 \times 5 \\
& =4.17\end{aligned}$ & $\mathrm{H}$ & 4 \\
\hline LG & $24 \%$ & $24 \% / 24 \%=1 \times 5=5$ & $\mathrm{EH}$ & 5 \\
\hline
\end{tabular}
indicators registered (GHG 1, GHG 2, GHG 3). The rank was identified according to the level of the rating scale, which was realized by each case. The ranking appears in the table in Exhibit 5 in the previous example. It can be seen that
EXHIBIT 5 Example of the percentage of green performance shown on a five-point scale

Note: The best green performance score was $-24 \%$, and the most deteriorated green performance was score $+24 \%$.

Nokia is ranked first, followed by Apple and Huawei, the third rank is occupied by ZTE, the fourth by Samsung, and the last is LG.

Step 4: Computing the indices of the actions of each case for each category, following Migdadi (2018). This was done by dividing the number of actions taken by the case by the total number of actions. The example in the table in Exhibit 6 shows the procedure.

Step 5: Showing the action index on a five-point scale. This was done by multiplying the index by 5 .

Step 6: Attaching the indices of the actions to cases according to their ranks and identifying the significant actions. A significant action is one taken by a case (as shown by the rating scale) that is higher in rank than all the lower-ranked cases. (For more detail about the action indices, action rating, ranking, and significant actions, see Appendices 1 to 3).

Step 7: Developing the indicative models for each green indicator. For this purpose, the following procedures were adopted:

Step 7-1: Identifying all of the significant actions affecting the green indicator for each case.

Step 7-2: Summing the significant action indices all together. 
EXHIBIT 6 Example of computing the green indices of the actions

\begin{tabular}{|c|c|c|c|c|c|c|}
\hline Green actions & Apple & Huawei & ZTE & Samsung & LG & Nokia \\
\hline \multicolumn{7}{|l|}{ Reducing the use of energy by facilities } \\
\hline Investing in gas treatment facilities & & & & & 1 & \\
\hline Using natural ventilation and natural lighting & & 1 & & & & \\
\hline $\begin{array}{l}\text { Installing new energy-saving equipment and } \\
\text { designs }\end{array}$ & & 1 & & & & \\
\hline Total \# of actions taken by each case & 1 & 2 & 1 & 1 & 1 & 1 \\
\hline $\begin{array}{l}\text { Index }=\text { Total \# of actions taken/total number of } \\
\text { actions }\end{array}$ & $1 / 5=0.2$ & $2 / 5=0.4$ & $1 / 5=0.2$ & $1 / 5=0.2$ & $1 / 5=0.2$ & $1 / 5=0.2$ \\
\hline
\end{tabular}

EXHIBIT 7 Example of how to show the action indices on a five-point scale

\begin{tabular}{lllllll} 
Green actions & Apple & Huawei & ZTE & Samsung & LG & 0.2 \\
$\begin{array}{l}\text { Index of reducing the use } \\
\text { of energy by facilities }\end{array}$ & 0.2 & 0.4 & 0.2 & 0.2 & 0.2 \\
\begin{tabular}{l} 
The rating = index $\times 5$ \\
\hline
\end{tabular} & $0.2 \times 5=1.0$ & $0.4 \times 5=2.0$ & $0.2 \times 5=1.0$ & $0.2 \times 5=1.0$ & $0.2 \times 5=1.0$ & $0.2 \times 5=1.0$ \\
\hline
\end{tabular}

EXHIBIT 8 Example of developing an indicative model

\begin{tabular}{|c|c|c|c|c|c|}
\hline \multirow{2}{*}{$\begin{array}{l}\text { ZTE } \\
\text { Step 7-1 }\end{array}$} & \multicolumn{3}{|c|}{ Energy $=-24 \%$} & \multicolumn{2}{|l|}{ GHG $1=-26.5 \%$} \\
\hline & Index & Step 7-3 Relative & Step 7-5 Impact & Step 7-5 direct Impact on GHG 1 & Step 7-6 mediating \\
\hline Process redesign & 0.33 & $0.33 / 1.33=0.25$ & $-24 \% \times 0.25=-5.98 \%$ & $-26.5 \% \times 0.25=-6.64 \%$ & $5.98 \% \times 6.64 \%=-0.40 \%$ \\
\hline $\begin{array}{l}\text { Technological } \\
\text { improvement }\end{array}$ & 0.67 & $0.67 / 1.33=0.50$ & $-11.95 \%$ & $-13.28 \%$ & $-1.59 \%$ \\
\hline Product design & 0.33 & $0.33 / 1.33=0.25$ & $-5.98 \%$ & $-6.64 \%$ & $-0.40 \%$ \\
\hline Step 7-2 & 1.33 & & $-24 \%$ & $-26.5 \%$ & $-6.35 \%$ \\
\hline
\end{tabular}

Step 7-3: Dividing the index of each action by all of the indices of action computed in the previous step. The result is the relative impact of each action.

Step 7-4: Computing the average improvement in green performance by deducting the average improvement percentage in the green performance of the lower-ranked cases from that in the case showing greater improvement (for more details about this, see Appendix 4).

Step 7-5: Multiplying the relative impact of the action by the improved performance of the case. The result indicates the impact of the action on improving the green indicator.

Step 7-6: If the case has registered a significant improvement in energy in comparison with all of the lower-ranked cases, the indicative models will have a mediating impact on energy; accordingly, the indicative model will be developed first for its direct impact on reducing energy, and then for its direct impact on reducing GHG. Next, the direct impact on energy will be multiplied by the
EXHIBIT 9 Icons of the value-stream map of the green supply chain

\begin{tabular}{ll} 
Interpretation & Green business travel and transportation \\
& Green product design \\
& Green facilities management \\
& Green supplier process \\
\hline & Green customer practices \\
\hline
\end{tabular}

direct impact on reducing GHG emissions. The following example in the table in Exhibit 8 shows this.

Step 8: Developing a value-stream map of the green supply chain. The value-stream map is a flowchart of value, which has been 

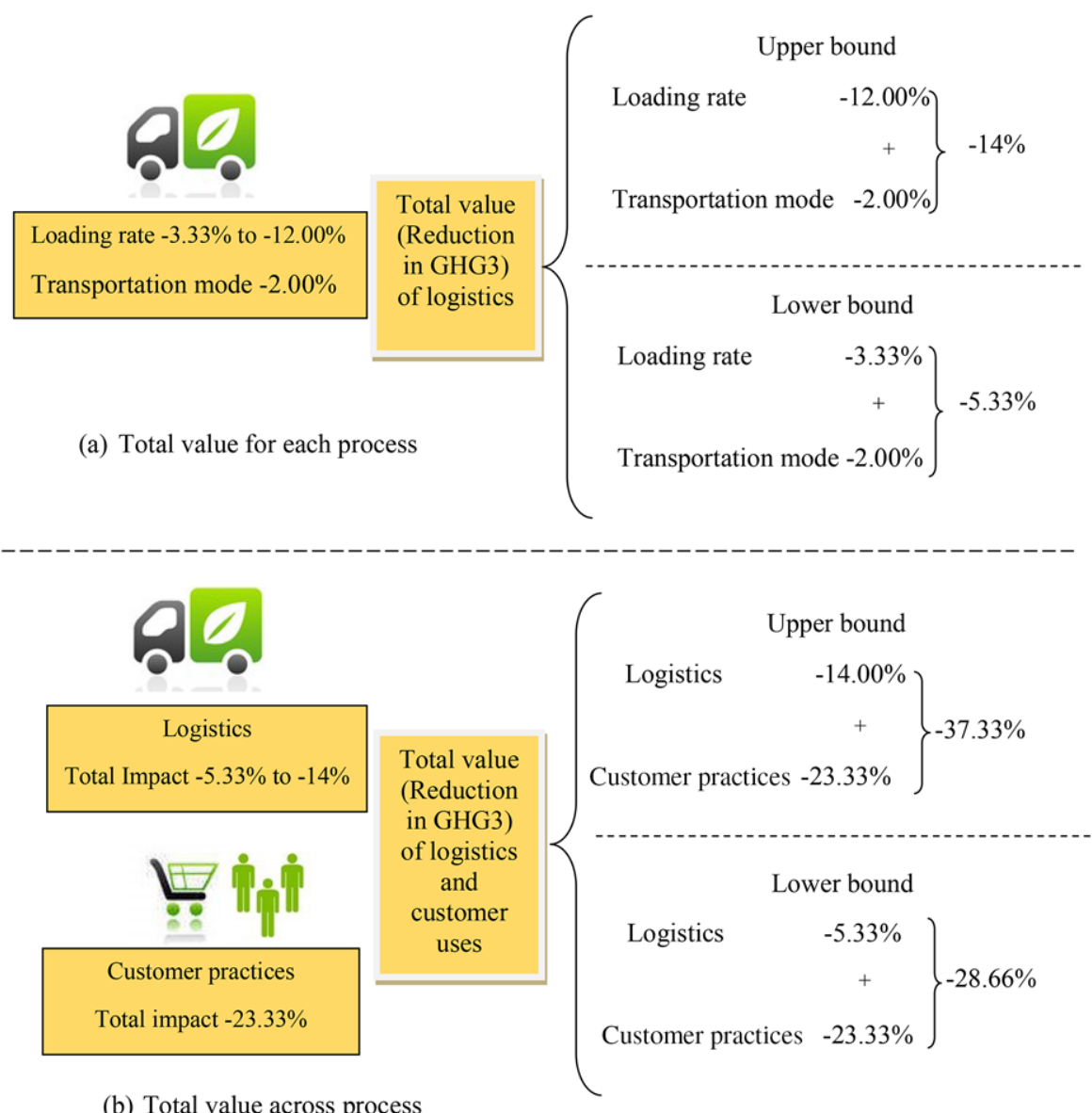

EXHIBIT 10 How to compute total value (total reduction in GHG emissions) [Color figure can be viewed at wileyonlinelibrary.com]

EXHIBIT 11 Degree of change in GHG emissions

\begin{tabular}{|c|c|c|c|c|c|c|c|c|c|c|c|}
\hline \multicolumn{4}{|c|}{ GHG 1} & \multicolumn{4}{|c|}{ GHG 2} & \multicolumn{4}{|c|}{ GHG 3} \\
\hline Case & $\%$ & $\begin{array}{c}\text { scale } \\
5 \\
\text { points }\end{array}$ & Level & Case & $\%$ & $\begin{array}{c}\text { Scale } \\
5 \\
\text { points }\end{array}$ & Level & Case & $\%$ & $\begin{array}{c}\text { scale } \\
5 \\
\text { points }\end{array}$ & Level \\
\hline Nokia & $-24 \%$ & 5 & $\mathrm{EH}$ & Apple & $-7 \%$ & 1.46 & $\mathrm{~L}$ & Samsung & $-14 \%$ & 2.92 & $\mathrm{M}$ \\
\hline Apple & $-7 \%$ & 1.46 & $\mathrm{~L}$ & Nokia & $-7 \%$ & 1.46 & $\mathrm{~L}$ & Nokia & $-6 \%$ & 1.25 & $\mathrm{~L}$ \\
\hline Huawei & $-5 \%$ & 1.02 & $\mathrm{~L}$ & ZTE & $-4.7 \%$ & 0.94 & EL & ZTE & $-4 \%$ & 0.83 & EL \\
\hline ZTE & $4.7 \%$ & 0.94 & EL & Huawei & $-2 \%$ & 0.33 & EL & LG & $-2 \%$ & 0.42 & EL \\
\hline Samsung & $20 \%$ & 4.17 & $\mathrm{H}$ & LG & $9 \%$ & 1.88 & $\mathrm{~L}$ & Huawei & $18 \%$ & 3.75 & $\mathrm{H}$ \\
\hline LG & $24 \%$ & 5 & $\mathrm{EH}$ & Samsung & $24 \%$ & 5 & $\mathrm{EH}$ & & & & \\
\hline
\end{tabular}


EXHIBIT 12 Green supply chain management actions taken to reduce GHG 1 emissions

\begin{tabular}{|c|c|c|c|}
\hline \multicolumn{4}{|l|}{ Production process } \\
\hline Process redesign & Frequency $(N=6)$ & Energy use & Frequency $(N=6)$ \\
\hline $\begin{array}{l}\text { Reengineering of the process so as to use } \\
\text { hydroelectricity rather than fossil fuels }\end{array}$ & 1 & Producing the firm's own renewable energy & 1 \\
\hline Engaging in lean production & 1 & $\begin{array}{l}\text { Signing long-term, renewable, energy } \\
\text { purchase contracts; Supporting new, local } \\
\text { projects that meet the firm's robust } \\
\text { renewable energy sourcing principles }\end{array}$ & 1 \\
\hline \multirow[t]{2}{*}{ Technological improvement } & Frequency $(N=6)$ & Launching energy conservation programs & 1 \\
\hline & & $\begin{array}{l}\text { Configuring the building automation system } \\
\text { for automatic maximum savings based on } \\
\text { conditions outside }\end{array}$ & 1 \\
\hline $\begin{array}{l}\text { Fully implementing e-Kanban (electronic JIT } \\
\text { pull system for moving material from } \\
\text { suppliers toward producers according to } \\
\text { customers' orders) }\end{array}$ & 1 & $\begin{array}{l}\text { Operational and technological measures of } \\
\text { energy consumed }\end{array}$ & 1 \\
\hline $\begin{array}{l}\text { Making managerial and technological } \\
\text { improvements, setting up an electronic } \\
\text { information management board }\end{array}$ & 1 & $\begin{array}{l}\text { Energy conservation through introducing } \\
\text { third-party experts to assess energy } \\
\text { efficiency }\end{array}$ & 1 \\
\hline \multicolumn{4}{|l|}{ Product redesign } \\
\hline & Frequency $(N=6)$ & & Frequency $(N=6)$ \\
\hline Optimizing mobile phone packaging & 3 & $\begin{array}{l}\text { Employing the International Organization } \\
\text { for Standardization (ISO), ISO } 14040 \\
\text { /14044 standards as the basis for } \\
\text { life-cycle assessments performed on the } \\
\text { firm's products }\end{array}$ & 1 \\
\hline $\begin{array}{l}\text { Considering alternatives for substances } \\
\text { designated "to be avoided" }\end{array}$ & 1 & & \\
\hline \multicolumn{4}{|l|}{ Business travel and transportation } \\
\hline Change work venue & Frequency $(N=6)$ & Using of group transportation & Frequency $(N=6)$ \\
\hline Employees working from their homes & 1 & Growing the firm's coach/bus program & 1 \\
\hline Encouraging the use of virtual meetings & 2 & & \\
\hline Use of sustainable travel facilities & Frequency $(N=6)$ & Setting up a dedicated transit center & 1 \\
\hline Adding new electric vehicle charging ports & 1 & $\begin{array}{l}\text { Organizing shuttle buses between hotels, } \\
\text { offices, and airports }\end{array}$ & 1 \\
\hline $\begin{array}{l}\text { Choosing shuttle buses that run on } \\
\text { renewable energy }\end{array}$ & 1 & Travel route management & Frequency $(N=6)$ \\
\hline $\begin{array}{l}\text { Encouraging the use of electric or } \\
\text { low-emission cars }\end{array}$ & 2 & $\begin{array}{l}\text { Eliminating the need for employees to } \\
\text { travel }\end{array}$ & 1 \\
\hline Providing new campus bicycles & 1 & $\begin{array}{l}\text { Engaging in internal lobbying and guidance } \\
\text { to reduce the need for internal business } \\
\text { travel }\end{array}$ & 2 \\
\hline
\end{tabular}

created to show the impact of moving products and services along the supply chain. "Value" in the present research is the percentage of reduction in GHG emissions across the supply chain, whether via upstream, core, or downstream processes. The processes were presented by using the icons as presented in the table in Exhibit 9. Under each process, the categories of action were presented, and the percentage of reduction in GHG emissions was related to each action. Each kind of GHG emission was presented in a different color, and the accumulated percentages of each kind of GHG were computed to find an overall GHG. The purpose of developing this map was to make it easier to read the results. The total value (total reduction in GHG emission) was computed for each process and across processes as presented in Exhibit 10.

\section{DATA ANALYSIS AND FINDINGS}

\subsection{The degree of change in GHG emissions}

The table in Exhibit 11 shows the degree of change in the GHG emissions. It can be seen that the positive change in GHG 1 emissions is wider than in the other indicators: the change varied between $-4.7 \%$ and $-24 \%$ for GHG 1 emissions. However, the range of positive change of GHG 3 emissions is wider than the change in GHG 2 emissions, which was between $-2 \%$ and $-14 \%$ for GHG 3 emissions, and between $-2 \%$ and $-7 \%$ for GHG 2 emissions. In addition, the negative performance of GHG 2 emissions is wider than that of GHG 1 and GHG 3 emissions; it is between $9 \%$ and $24 \%$. Being the top-ranked case in terms of any indicator does not mean being the top ranked in other indicators. For example, Nokia was the top ranked in terms of GHG 1 emissions, but 
EXHIBIT 13 Green supply chain management actions taken to reduce GHG 2 emissions

\begin{tabular}{|c|c|c|c|}
\hline Accreditation of facilities & Frequency $(N=6)$ & Upgrading facilities & Frequency $(\mathrm{N}=6)$ \\
\hline Meeting a LEED Gold certification & 1 & $\begin{array}{l}\text { Upgrading heating, ventilation, and air-conditioning } \\
\text { systems }\end{array}$ & 1 \\
\hline $\begin{array}{l}\text { Meeting ISO } 50001 \text { international standard } \\
\text { certification }\end{array}$ & 2 & Replacing old facilities & 1 \\
\hline Reducing energy use by the facilities & Frequency $(N=6)$ & Controlling energy use by the facilities & Frequency $(N=6)$ \\
\hline Investing in gas treatment facilities & 1 & Retro-commissioning building and lighting controls & 1 \\
\hline Upgrading to LED lighting & 2 & Installing water heating meters & 1 \\
\hline $\begin{array}{l}\text { Installing natural ventilation and natural } \\
\text { lighting }\end{array}$ & 1 & $\begin{array}{l}\text { Installing sensors to collect data about electricity, } \\
\text { temperature, humidity, flow, and pressure }\end{array}$ & 2 \\
\hline $\begin{array}{l}\text { Installing new energy-saving equipment and } \\
\text { designs }\end{array}$ & 1 & Tracking important energy efficiency indicators & 1 \\
\hline \multirow[t]{3}{*}{ Using renewable sources of energy } & 2 & $\begin{array}{l}\text { Integrating the software for iEnergy network } \\
\text { energy management based in cloud technology }\end{array}$ & 1 \\
\hline & & $\begin{array}{l}\text { Setting up a comprehensive software platform that } \\
\text { will increase the automatic collection and } \\
\text { reporting of environmental data }\end{array}$ & 1 \\
\hline & & $\begin{array}{l}\text { Installing electrical submeters to monitor the use of } \\
\text { electric power }\end{array}$ & 1 \\
\hline
\end{tabular}

ranked second in terms of GHG 3 emissions. Moreover, the level of relative performance of a case is not always the same for all indicators. For example, Nokia's performance was extremely high in terms of GHG 1 emissions, but low in terms of GHG 2 and 3 emissions. In addition, the cases that registered negative performance can also register positive performance. Samsung, for example, registered negative performance in terms of GHG 1 and 2, but positive performance in terms of GHG 3 .

\subsection{The adopted green supply chain management actions}

The table in Exhibit 12 shows the green supply chain management actions taken to reduce GHG 1 emissions. It can be seen that the actions were divided into three major categories: production process actions, product redesign and business travel actions. The categories of the production process were process redesign, technological improvement, and energy use. The categories related to business travel were changing the work venue, using sustainable travel facilities, using group transportation, and travel route management. In each category, the frequency of actions taken by the mobile phone producers was counted; most of the actions were taken by only one case. However, three actions were taken related to product redesign, the most frequencly action was optimizing mobile phone package.

The table in Exhibit 13 shows the actions taken by the management of the green supply chain to reduce GHG 2 emissions. It can be seen that the categories of action taken were accreditation of facilities, reducing the use of energy in the facilities, upgrading the facilities, and controlling the energy use in the facilities. Different actions were taken in each category. Most of the actions were taken by only one case.

The table in Exhibit 14 shows the green supply chain management actions taken to reduce GHG 3 emissions. It can be seen that the actions can be divided into three general categories: management of the suppliers' relationship, management of the logistics, and customer practices. The actions taken in managing the relations with suppliers were classified either as auditing suppliers or as helping suppliers. The logistics management actions were classified according to the loading rate of the transportation facilities or the mode of transportation. The customer practices categories were either to provide customers with more efficient products or to educate customers. Different actions were taken in each category. The frequency with which the actions were taken varied across the categories.

\subsection{The effective green supply chain management actions in reducing $\mathrm{GHG}$ emissions}

The table in Exhibit 15 shows the indicative models for the impact of green supply chain management actions in reducing GHG 1 emissions. It can be seen that all of the categories of actions in the production process have an effective impact on reducing GHG 1 emissions. Two categories have both a direct and an indirect impact on reducing GHG 1 emissions. The impact of different categories of production actions is different: the most effective action was controlling energy use, followed by technological improvement, and the action with the lowest direct impact was process redesign. The maximum reductions were $-13.14 \%,-11.95 \%$, and $-5.98 \%$, respectively. These results supported H3. However, the indirect impact was through energy saving, the most effective was technological improvement, at $-1.59 \%$, followed by process redesign at $-0.4 \%$.

The product redesign had a direct and indirect impact on reducing GHG 1 emissions. The impact was between $-5.98 \%$ and $-17.47 \%$. However, the indirect impact was $-0.4 \%$. The maximum direct impact of product redesign was more than the categories of action regarding the production process. Two out of four categories of actions regarding business travel had a significant impact on reducing GHG 1 emissions. These categories were using group business travel facilities and using sustainable travel facilities. The impact of these categories was only direct; the impact was $-6.18 \%$ for using group business travel facilities, and within a range of $-4.93 \%$ to $-9.27 \%$ for using sustainable travel facilities. 
EXHIBIT 14 Green supply chain management actions taken to reduce GHG 3 emissions

\begin{tabular}{|c|c|c|c|}
\hline \multicolumn{4}{|l|}{ Suppliers relationship management } \\
\hline Auditing suppliers & Frequency $(N=6)$ & Helping suppliers & Frequency $(N=6)$ \\
\hline $\begin{array}{l}\text { Conduct audits and inspection for suppliers } \\
\text { to find opportunities for energy efficiency }\end{array}$ & 4 & $\begin{array}{l}\text { Developed the Clean Energy Portal, an online platform } \\
\text { to help suppliers identify commercially viable } \\
\text { renewable energy solutions }\end{array}$ & 1 \\
\hline \multirow[t]{4}{*}{$\begin{array}{l}\text { Impose a comprehensive qualification } \\
\text { process for all new suppliers, including } \\
\text { suppliers' sustainability systems }\end{array}$} & 2 & $\begin{array}{l}\text { Update policy guidance and tools to help suppliers } \\
\text { develop commercially viable strategies to achieve } \\
\text { renewable energy }\end{array}$ & 1 \\
\hline & & $\begin{array}{l}\text { Train suppliers to identify opportunities for energy } \\
\text { efficiency }\end{array}$ & 4 \\
\hline & & $\begin{array}{l}\text { Help suppliers to analyze root causes and identify ways } \\
\text { to mitigate issues }\end{array}$ & 3 \\
\hline & & $\begin{array}{l}\text { Encourage suppliers to develop energy metering } \\
\text { systems, audit their energy use, and identify } \\
\text { opportunities to cut energy use and } \mathrm{CO}_{2} \text { emissions }\end{array}$ & 2 \\
\hline \multicolumn{4}{|l|}{ Logistics management } \\
\hline Loading rate of transportation facilities & Frequency $(N=6)$ & Transportation mode & Frequency $(N=6)$ \\
\hline $\begin{array}{l}\text { Using less packaging so less fuel is consumed } \\
\text { when products travel by air and sea }\end{array}$ & 3 & Using containers and ships & 2 \\
\hline $\begin{array}{l}\text { Making packaging lighter so less fuel is } \\
\text { consumed when products travel by air and } \\
\text { sea }\end{array}$ & 3 & & \\
\hline \multicolumn{4}{|l|}{ Customer practices } \\
\hline $\begin{array}{l}\text { Providing customers with more efficient } \\
\text { products }\end{array}$ & Frequency $(N=6)$ & Educating customers & Frequency $(N=6)$ \\
\hline $\begin{array}{l}\text { Make advancements in products' efficiency } \\
\text { so mobile phones can charged only once a } \\
\text { day }\end{array}$ & 1 & $\begin{array}{l}\text { Completion of an environmental product declaration, } \\
\text { or EPD, containing, product-related information } \\
\text { based on regulatory requirements for customers }\end{array}$ & 1 \\
\hline Using high-efficiency chargers & 1 & & \\
\hline Incorporating an ultra-power-saving mode & 2 & & \\
\hline
\end{tabular}

EXHIBIT 15 Effective actions in reducing GHG 1 emissions

\begin{tabular}{|c|c|c|c|}
\hline Category of actions & \multicolumn{2}{|c|}{ Direct reduction in GHG 1 emission (\%) } & $\begin{array}{l}\text { Indirect reductions in GHG } 1 \text { emission } \\
\text { through reducing energy consumption (\%) }\end{array}$ \\
\hline \multicolumn{4}{|l|}{ Production process } \\
\hline Process redesign & $-5.98 \%$ & - & $-0.40 \%$ \\
\hline Technological improvement & - & $-11.95 \%$ & $-1.59 \%$ \\
\hline Energy use & - & $-13.14 \%$ & - \\
\hline \multicolumn{4}{|l|}{ Product redesign } \\
\hline Product design & $-5.98 \%$ & $-17.47 \%$ & $-0.40 \%$ \\
\hline \multicolumn{4}{|l|}{ Business travel and transportation } \\
\hline Use of group transportation & $-6.18 \%$ & - & - \\
\hline Use of sustainable travel facilities & $-4.93 \%$ & $-9.27 \%$ & \\
\hline
\end{tabular}

EXHIBIT 16 Effective actions in reducing GHG 2 emissions

\begin{tabular}{llc} 
Actions & $\begin{array}{l}\text { Reduction in GHG 2 emissions } \\
(\%)\end{array}$ & $-13.73 \%$ \\
\hline $\begin{array}{c}\text { Controlling the use of } \\
\text { energy in facilities }\end{array}$ & $-4.36 \%$ & $-14.79 \%$ \\
\hline $\begin{array}{c}\text { Accreditation of facilities } \\
\text { Reducing the use of energy } \\
\text { in facilities }\end{array}$ & $-7.63 \%$ & - \\
\hline
\end{tabular}

The table in Exhibit 16 shows the indicative models of the impact of actions taken by the management of green supply chains to reduce
GHG 2 emissions. It can be seen that only three actions have a direct impact on reducing GHG 2 emissions, and two of these actions have a range of impacts. These actions involved controlling the use of energy in the facilities and the accreditation of facilities. The impact was between $-4.36 \%$ and $-13.73 \%$ for controlling the energy use in the facilities; however, the impact of accrediting the facilities ranged between $-7.63 \%$ and $-14.79 \%$. The impact of reducing the energy use of facilities was $-6.11 \%$. The most effective action was the accreditation of facilities.

The table in Exhibit 17 shows the indicative models to reduce GHG 3 emissions. It can be seen that two categories had a significant impact, 
EXHIBIT 17 Effective actions in reducing GHG 3 emissions

\begin{tabular}{|lll}
\hline Actions & $\begin{array}{l}\text { Reduction in GHG } 3 \text { emission } \\
(\%)\end{array}$ \\
\hline $\begin{array}{l}\text { Logistics management } \\
\begin{array}{l}\text { Loading rate of } \\
\text { transportation facilities }\end{array}\end{array}$ & $-3.33 \%$ & $-12.00 \%$ \\
\hline $\begin{array}{l}\text { Transportation mode } \\
\text { Customer practices }\end{array}$ & $-2 \%$ & - \\
\hline $\begin{array}{l}\text { Educating customers } \\
\text { Providing customers with } \\
\text { more efficient products }\end{array}$ & $-3.33 \%$ & $-20 \%$ \\
\hline
\end{tabular}

namely, logistics management and customer practices. The loading rate of the transportation facilities had more impact than the mode of transportation; it ranged from $-3.33 \%$ to $-12 \%$ for the loading rate of the transportation facilities, while the impact of the transportation mode was $-2 \%$. This result supported $\mathrm{H} 1$, but not $\mathrm{H} 2$. Providing customers with more efficient products had the greatest impact on reducing GHG 3 emissions, with a $-20 \%$ reduction. The impact of educating customers was $-3.33 \%$; this result supports $\mathrm{H} 8$. The management of the relationship with suppliers had no significant impact on reducing GHG 3 emissions. Accordingly, hypotheses $\mathrm{H} 4, \mathrm{H} 5, \mathrm{H} 6$, and $\mathrm{H} 7$ are rejected.

\subsection{The value-stream map of the green supply chain GHG for mobile phone producers}

The figure in Exhibit 18 shows the value-stream map for the effective supply chain management of mobile phone producers (to have better insight about how the values were computed, see Exhibit 10). It can be seen that three processes contribute to reducing GHG 1 emissions, namely, business travel, product redesign, and the production process, (the color of labels under these processes is blue). It can be seen that the most effective process in reducing GHG 1 emissions was making changes in the production process. The total impact was between $-15.13 \%$ and $-31.07 \%$. The total impact of changes in product design ranged between $-0.4 \%$ and $-17.40 \%$, and the total impact of altering business travel was between $-11.11 \%$ and $-15.45 \%$. The total impact of green facilities management was between $-18.10 \%$ and $-34.63 \%$, (the color of label under this processes is orange). Two processes had a significant impact on reducing GHG 3 emissions were logistics management and customer practices, (the color of labels under these processes is yellow). The total impact of the customer practices process was $-23.33 \%$, and it exceeded the impact of the logistics process, which was between $-5.33 \%$ and $-14.00 \%$. The total impact of reducing GHG 1 emissions was mostly within the range of $-26.46 \%$ to $-63.92 \%$, followed by reducing GHG 3 emissions, which ranged between $-28.66 \%$ and $-37.33 \%$, and the lowest total impact was for GHG 2 with a range of between $-18.10 \%$ and $-34.63 \%$.

\section{5 | DISCUSSION}

The greater improvement in the reduction of GHG 1 emissions compared with the reductions of the other indicators is due to the fact that the production process, as the greatest contributor to GHG 1 emissions, causes the greatest amount of concern to the producers of mobile phones. The statistics show that $85 \%$ of emissions come from the production process (Suckling \& Lee, 2015). The range of improvement in GHG 3 emissions was greater than those realized from GHG 2 reductions, as GHG 3 emissions are related to many processes, such as logistics, customer use, etc. Thus, the accumulated improvement can exceed the improvements in GHG 2 emissions.

The impact of energy use in the production process on reducing GHG 1 was greater that than for process redesign and

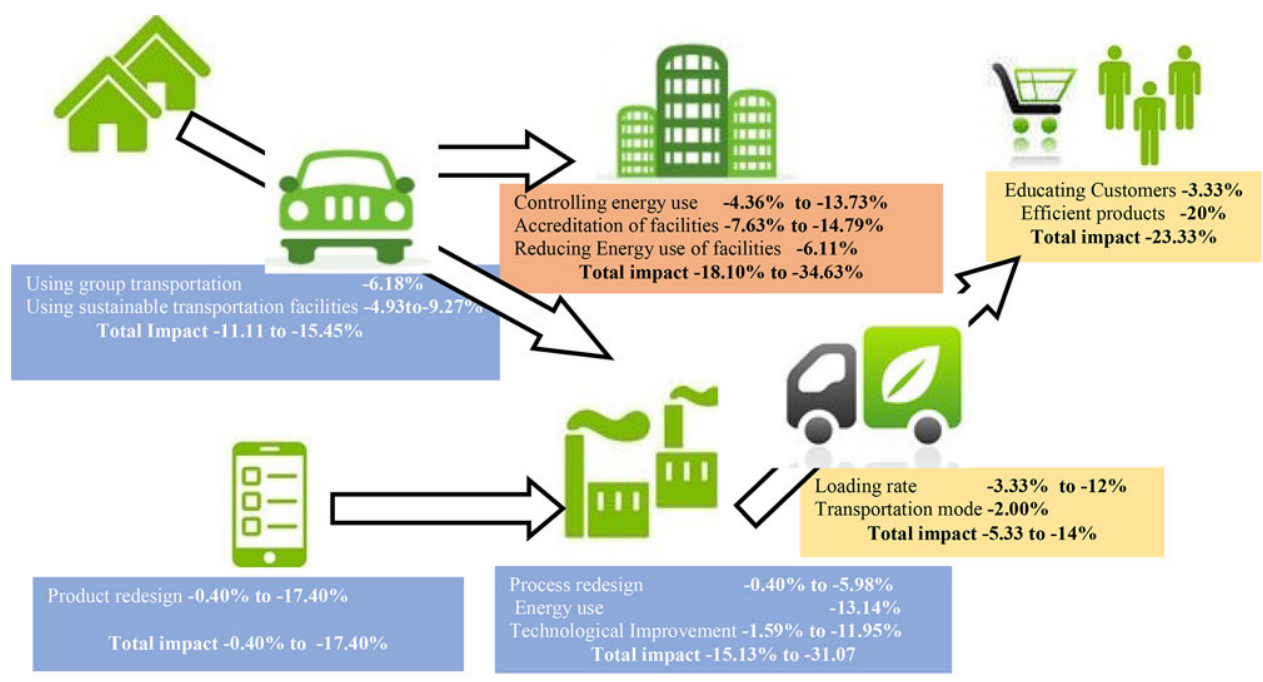

Totals

\begin{tabular}{|l|c|}
\multicolumn{1}{|c|}{} & \multicolumn{1}{c|}{ Totals } \\
\hline GHG1 & $-26.64 \%$ to $-63.92 \%$ \\
\hline GHG2 & $\mathbf{- 1 8 . 1 0} \%$ to $-\mathbf{3 4 . 6 3} \%$ \\
\hline GHG3 & $\mathbf{- 2 8 . 6 6 \%}$ to $\mathbf{- 3 7 . 3 3} \%$ \\
\hline
\end{tabular}

EXHIBIT 18 Value-stream map of the green supply chain GHG by mobile phone producers [Color figure can be viewed at wileyonlinelibrary.com] 
technological improvement, as the action of reducing energy usage has a more direct impact on GHG 1 emissions than on other changes, especially if corporations are committed to using sustainable energy or reducing energy use as was the case in the effective corporations in the present research. The use of sustainable traveling facilities has more impact than using group transportation facilities, as sustainable traveling facilities have a more direct impact on the amount of fuel used than group transportation does. Many factors can impact the use of group transportation, such as the willingness of employees to use it, the availability of group transportation, etc., but the replacing of facilities by sustainable equivalents, whether it is a group or a single facility, has a direct impact, leaving aside the employees' willingness to use it or its availability.

Product redesign had the most significant impact on reducing GHG 1 emissions, as the redesign of a product-whether by using different materials or substances that require less energy in the production process-will have an impact on the production process. Using less packaging will also reduce packing time. Furthermore, the assessment of environmental impact during a product's lifecycle will have an impact on the design requirements; it will call for more recycling, remanufacturing, and upcycling of products, which will reduce the GHG 1 emissions of the production process. The study of Migdadi (2016) confirms that some of the best practices of mobile phones producers' operations strategy were related to recycling.

The accreditation of facilities has provided greater improvement in the reduction of GHG 2 emissions than controlling the energy use of facilities and reducing the use of facilities. This indicates that the accreditation of energy savings by using Leaderships in Energy and Environmental Design (LEED; United States Green Building Council, 2018) or International Organization for Standardization (ISO) 50001 standards was more effective than taking action without accreditation. For example, ISO 50001 (ISO, 2018) is based on the management system model of continual improvement, which is also used in other wellknown standards, such as ISO 9001 and ISO 14001. This makes it easier for organizations to integrate energy management into their overall efforts to improve quality and environmental management (ISO, 2018). Adopting the LEED system also includes a set of rating systems for the design, construction, operation, and maintenance of green buildings, homes, and neighborhoods, which aims to help building owners and operators be environmentally responsible and use resources efficiently (US Green Building Council, 2018). The accreditation process requires auditing, either internally or externally, to confirm conformance. Moreover, the accreditation requires periodic evaluation by the accreditation body.

The management of supplier relations had no significant impact on reducing GHG 3 emissions. The results of the actions index in Appendix 2 show that while some actions were taken extremely often, such as auditing suppliers, and some actions taken moderately, may often help suppliers, but these actions did not guarantee an improvement in GHG 3 emissions. Most mobile phones over the last few years have continued to be made in-house by original equipment manufacturers, and few are produced by outsourced manufacturers, such as electronic manufacturing services (EMS; IHS Markit, 2014). Accordingly, the proportion of suppliers' GHG 3 emissions can be very small in compari- son with other processes, such as logistics or customer use. The loading rate of transportation facilities caused more reductions in GHG 3 emissions than the mode of transportation. This can be related to the fact that the most widely adopted outboard mode by most producers is aircraft. For example, Apple almost certainly ships by air, despite the higher logistical costs, for two reasons. The first is the cost of working capital. Ocean shipments take 30 days or more to cross the Pacific and reach their final destination in Apple's retail stores, versus a mere 3 to 5 days for air freight (Flexport, 2018). However, for inboard freight the modes are more diverse than for outboard so there are some effects, but the emissions related to outboard shipments may be more significant because of the use of air shipment.

Providing customers with more efficient products had more impact than educating customers. Because the impact of educating customers about environmentally friendly use requires voluntary action by the customer, the corporations have no control over it. Moreover, educating customers in general is a problem of marketing in itself, as many companies do not differentiate between marketing and educating. "Educating" means putting the product in the context of its actual use, so the producer should communicate advice about the product's use in simple, professional, and familiar words (Craig, 2015). This can be challenging in the context of green product use, as the adoption of green practices by customers depends on his/her willingness to protect the environment.

\section{6 | CONCLUSIONS}

\subsection{Contribution and results}

The environmental impact of the mobile phone manufacturing industry is becoming increasingly significant. GHG emissions from this industry will reach more than $14 \%$ of global emissions. The production process is responsible for about $85 \%$ of mobile phone production emissions; accordingly, it seems prudent to study the most effective supply chain actions to reduce the environmental impact of this sector. This paper has reported on the literature regarding effective actions taken in other sectors, and surveyed some actions or action categories; however, many of these studies showed limited concern about differentiating among GHG 1, 2, and 3 emissions. Accordingly, this study bridged the gap in the literature by investigating all the action categories for mobile phone producers.

The study found that the total improvement in GHG 1 was more than for GHG 2 or GHG 3. The most effective actions for reducing GHG 1 emissions were saving energy in the production process, addressing product design, and using sustainable transportation facilities. However, the most effective action for reducing GHG 2 emissions was the accreditation of facilities, and the most effective actions for reducing GHG 3 emissions were the loading rate of the transportation facilities and providing customers with more efficient products. The indicative models were developed in this research for measuring the impact of green supply chain actions on GHG emissions, and the research also provided a value-stream map, which shows the impact of all the supply chain actions in reducing GHG emissions. 


\section{2 | Implications, limitations, and future research}

The results of this study will help the supply chain managers of the mobile phone manufacturing industry adopt the effective actions reported by this study. Moreover, academics will improve their insights into the effective actions that can be taken by the managers of green supply chains in mobile phone manufacturing. This study can be used for teaching purposes and for conducting future research. The study is limited in terms of sample size, considering six corporations only, but the models developed by this study are still indicative. However, further studies with larger sample sizes could help in developing prediction models of greater validity. Certain aspects require further indepth investigation in future studies, such as the impact of saving energy in the production process, the accreditation of facilities, the adoption of sustainable transportation facilities, the management of supplier relations, and customer education.

\section{REFERENCES}

Azadeh, A., Raoofi, Z., \& Zarrin, M. (2015). A multi-objective fuzzy linear programming model for optimization of natural gas supply chain through a greenhouse gas reduction approach. Journal of Natural Gas Science and Engineering, 26, 702-710. Retrieved from https:// www.sciencedirect.com/science/article/abs/pii/S187551001500284X

Bazan, E., Jaber, M. Y., \& Zanoni, S. (2015). Supply chain models with greenhouse gases emissions, energy usage and different coordination decisions. Applied Mathematical Modelling, 3917, 5131-5151. Retrieved from https://www.sciencedirect.com/science/article/abs/pii/ S0307904X15002206

Belkhir, L., \& Elmeligi, A. (2018). Assessing ICT global emissions footprint: Trends to 2040 and recommendations. Journal of Cleaner Production, 177, 448-463. Retrieved from https://www.sciencedirect.com/ science/article/pii/S095965261733233X

Bjørn, A., \& Hauschild, M. Z. (2013). Absolute versus relative environmental sustainability: What can the cradle-to-cradle and ecoefficiency concepts learn from each other? Journal of Industrial Ecology, 172, 321-332. Retrieved from https://onlinelibrary.wiley.com/ doi/abs/10.1111/j.1530-9290.2012.00520.x

Blanco, C., Caro, F., \& Corbett, C. J. (2016). The state of supply chain carbon footprinting: Analysis of CDP disclosures by US firms. Journal of Cleaner Production, 135, 1189-1197. Retrieved from https://www. sciencedirect.com/science/article/pii/S0959652616308095

Boehme, S. E., Panero, M. A., Muñoz, G. R., Powers, C. W., \& Valle, S. N. (2009). Collaborative problem solving using an industrial ecology approach: The New York/New Jersey Harbor Economy-Wide Substance Flow Case Studies. Journal of Industrial Ecology, 135, 811829. Retrieved from https://onlinelibrary.wiley.com/doi/abs/10.1111/ j.1530-9290.2009.00166_2.x

Coskun, S., Ozgur, L., Polat, O., \& Gungor, A. (2016). A model proposal for green supply chain network design based on consumer segmentation. Journal of Cleaner Production, 110, 149-157. Retrieved from https:// www.sciencedirect.com/science/article/pii/S0959652615001857

Craig, W. (2015). Don't market to your customers; educate them instead. Retrieved from https://www.forbes.com/sites/williamcraig/2015/04/ 10/dont-market-to-your-customers-educate-them-instead/\#6c62bf $8 \mathrm{~d} 1 \mathrm{cfa}$

de Bakker, F. G. (2001). Product-oriented environmental management: Lessons from total quality management. Journal of Industrial Ecology, 52, 55-69. Retrieved from https://onlinelibrary.wiley.com/doi/ abs/10.1162/10881980152830132
Egilmez, G., Kucukvar, M., Tatari, O., \& Bhutta, M. K. S. (2014). Supply chain sustainability assessment of the US food manufacturing sectors: A life cycle-based frontier approach. Resources, Conservation and Recycling, 82, 8-20. Retrieved from https://www.sciencedirect.com/science/article/ pii/S0921344913002152

Elhedhli, S., \& Merrick, R. (2012). Green supply chain network design to reduce carbon emissions. Transportation Research Part D: Transport and Environment, 175, 370-379. Retrieved from https://www.sciencedirect. com/science/article/pii/S1361920912000168

Flexport. (2018). Does Apple ship iPhones by air or sea? Retrieved from https://www.flexport.com/blog/does-apple-ship-iphones-by-air-or-sea/

Global Reporting Initiative (GRI). (2018). About GRI. Retrieved from https://www.globalreporting.org/Information/about-gri/Pages/default. aspx

Good Electronics. (2015). iPhone footprint-85\% of $\mathrm{CO}_{2}$ emitted at manufacturing stage. Retrieved from: http://goodelectronics.org/iphonefootprint-85-of-co2-emitted-at-manufacturing-stage/

Guang Shi, V., Lenny Koh, S. C., Baldwin, J., \& Cucchiella, F. (2012). Natural resource based green supply chain management. Supply Chain Management: An International Journal, 171, 54-67. Retrieved from https:// www.emeraldinsight.com/doi/abs/10.1108/13598541211212203

Haddadsisakht, A., \& Ryan, S. M. (2018). Closed-loop supply chain network design with multiple transportation modes under stochastic demand and uncertain carbon tax. International Journal of Production Economics, 195, 118-131. Retrieved from https://www.sciencedirect. com/science/article/pii/S0925527317302931

Hsu, C. W., Kuo, T. C., Chen, S. H., \& Hu, A. H. (2013). Using DEMATEL to develop a carbon management model of supplier selection in green supply chain management. Journal of Cleaner Production, 56, 164172. Retrieved from https://www.sciencedirect.com/science/article/ pii/S095965261100343X

Huang, Y., Wang, K., Zhang, T., \& Pang, C. (2016). Green supply chain coordination with greenhouse gases emissions management: A gametheoretic approach. Journal of Cleaner Production, 112, 2004-2014. Retrieved from https://www.sciencedirect.com/science/article/pii/ S0959652615007532

IHS Markit. (2014). Rise of smartphones upends business prospects for outsourced manufacturers. London, UK: IHS Markit Ltd. Retrieved from https://technology.ihs.com/431471/rise-of-smartphones-upendsbusiness-prospects-for-outsourced-manufacturers

International Organization for Standardization (ISO). (2018). ISO 50001. Energy management system. Geneva: ISO. Retrieved from https://www. iso.org/iso-50001-energy-management.htm

Jaber, M. Y., Glock, C. H., \& El Saadany, A. M. (2013). Supply chain coordination with emissions reduction incentives. International Journal of Production Research, 511, 69-82. Retrieved from https://www. tandfonline.com/doi/abs/10.1080/00207543.2011.651656

Jardim, E. (2017). From smart to senseless: The global impact of 10 years of smartphones. Washington, DC: Greenpeace Inc. Retrieved from https:// www.greenpeace.org/usa/wp-content/uploads/2017/03/FINAL10YearsSmartphones-Report-Design-230217-Digital.pdf

Joshi, S. (1999). Product environmental life-cycle assessment using input-output techniques. Journal of Industrial Ecology, 3(2-3), 95120. Retrieved from https://onlinelibrary.wiley.com/doi/abs/10.1162/ 108819899569449

Matthews, H. S., \& Small, M. J. (2000). Extending the boundaries of lifecycle assessment through environmental economic input-output models. Journal of Industrial Ecology, 43, 7-10. Retrieved from https:// onlinelibrary.wiley.com/doi/abs/10.1162/108819800300106357

Migdadi, Y. (2015). The leading practices of green mobile telecommunication base station design. International Journal of Green Computing 
(IJGC), 62, 43-52. Retrieved from https://www.igi-global.com/article/ the-leading-practices-of-green-mobile-telecommunication-basestation-design/166613

Migdadi, Y. K. A. A. (2016). Identifying the best practices in green operations strategy of leading mobile phone producers. International Journal of Business Excellence, 91, 92-112. Retrieved from https://www. inderscienceonline.com/doi/abs/10.1504/IJBEX.2016.073377

Migdadi, Y. K. A. A. (2018). Identifying the best practices of airlines' green operations strategy: A cross-regional worldwide survey. Environmental Quality Management, 281, 21-33. Retrieved from https:// onlinelibrary.wiley.com/doi/abs/10.1002/tqem.21575

Migdadi, Y. K. A. A., \& Elzzqaibeh, D. A. S. I. (2018). The evaluation of green manufacturing strategies adopted by ISO 14001 certificate holders in Jordan. International Journal of Productivity and Quality Management, 231, 90-109. Retrieved from https://www.inderscienceonline. com/doi/abs/10.1504/IJPQM.2018.088610

Migdadi, Y. K. A. A., \& Omari, A. A. (2019). Identifying the best practices in green operations strategy of hospitals. Benchmarking: An International Journal. Retrieved from https://doi.org/10.1108/BIJ-09-2017-0242

Nakamichi, K., Hanaoka, S., \& Kawahara, Y. (2016). Estimation of cost and $\mathrm{CO}_{2}$ emissions with a sustainable cross-border supply chain in the automobile industry: A case study of Thailand and neighboring countries. Transportation Research Part D: Transport and Environment, 43, 158-168. Retrieved from https://www.sciencedirect.com/ science/article/pii/S136192091600002X

StatCounter. (2018). Mobile vendor market share worldwide Sept. 2017-Sept. 2018. Retrieved from http://gs.statcounter.com/vendormarket-share/mobile/worldwide/2018

Suckling, J., \& Lee, J. (2015). Redefining scope: The true environmental impact of smartphones? The International Journal of Life Cycle Assessment, 208, 1181-1196. Retrieved from https://link.springer. com/article/10.1007/s11367-015-0909-4

United Nations (UN) Environment. (2017). Emission gap report 2017. New York City: United Nations. Retrieved from https://www.unenvironment. org/resources/emissions-gap-report-2017

US Green Building Council. (2018). How LEED works. Atlanta, USA. Retrieved from https://new.usgbc.org/leed\#how-leed-works

Wilson, M. (2018). Smartphones are killing the planet faster than anyone expected. Fastcompany. Retrieved from https://www.fastcompany.com/ 90165365/smartphones-are-wrecking-the-planet-faster-than-anyoneexpected
World Business Council for Sustainable Development and World Resources Institute. (2017). The greenhouse gas protocol: A corporate accounting and reporting standards (11th ed.). Geneva, Switzerland: World Business Council for Sustainable Development. Washington, DC: World Resources Institute. Retrieved from https://ghgprotocol.org/ sites/default/files/standards/ghg-protocol-revised.pdf

Zhang, Q., Shah, N., Wassick, J., Helling, R., \& Van Egerschot, P. (2014). Sustainable supply chain optimisation: An industrial case study. Computers \& Industrial Engineering, 74, 68-83. Retrieved from https://www. sciencedirect.com/science/article/abs/pii/S0360835214001478

Zhang, H., \& Yang, F. (2016). On the drivers and performance outcomes of green practices adoption: An empirical study in China. Industrial Management \& Data Systems, 1169, 2011-2034. Retrieved from https:// www.emeraldinsight.com/doi/abs/10.1108/IMDS-06-2015-0263

\section{AUTHOR'S BIOGRAPHY}

Y. K. A.-A. Migdadi is an associate professor of operations management at the Management and Marketing department, Qatar University, Qatar. He was awarded a PhD in operations strategy from Bradford University, UK, and awarded a BA and an MBA from Yarmouk University, Jordan. He worked as an assistant and associate professor of operations management at Business Administration department, Yarmouk University, Jordan, and worked as a teaching assistant and a researcher of operations and information management at Bradford University, School of Management, UK. His main research interest is reporting operations strategy: best practices, taxonomies, process, and typologies.

How to cite this article: Migdadi YKA-A. The effective practices of mobile phone producers' green supply chain management in reducing GHG emissions. Environ Qual Manage. 2019;28:17-32. https://doi.org/10.1002/tqem.21619 


\section{APPENDIX 1: INDICES OF GHG 1 SUPPLY CHAIN MANAGEMENT ACTIONS}

\begin{tabular}{|c|c|c|c|c|c|c|c|c|c|c|c|c|c|c|c|}
\hline \multirow[b]{2}{*}{$\begin{array}{c}\text { Corporatio } \\
n\end{array}$} & \multicolumn{3}{|c|}{ GHG 1} & \multicolumn{3}{|c|}{ Process redesign } & \multicolumn{3}{|c|}{$\begin{array}{l}\text { Technological } \\
\text { improvement }\end{array}$} & \multicolumn{3}{|c|}{ Energy usage } & \multicolumn{3}{|c|}{ Product design } \\
\hline & $\%$ & $\begin{array}{c}\text { Scal } \\
\text { e }\end{array}$ & $\begin{array}{c}\text { Leve } \\
1\end{array}$ & $\begin{array}{c}\text { Inde } \\
\mathbf{x}\end{array}$ & $\begin{array}{c}\text { Scal } \\
\mathrm{e}\end{array}$ & $\begin{array}{c}\text { Leve } \\
1\end{array}$ & Index & Scale & Level & $\begin{array}{c}\text { Inde } \\
\mathbf{x}\end{array}$ & $\begin{array}{c}\text { Scal } \\
\mathrm{e}\end{array}$ & $\begin{array}{c}\text { Leve } \\
1\end{array}$ & $\begin{array}{c}\text { Inde } \\
x\end{array}$ & $\begin{array}{c}\text { Scal } \\
\mathrm{e}\end{array}$ & $\begin{array}{c}\text { Leve } \\
1\end{array}$ \\
\hline Nokia & -0.24 & 5 & $\mathrm{EH}$ & 0 & 0 & None & 0 & 0 & None & 0 & 0 & None & 1 & 5 & $\mathrm{EH}$ \\
\hline Apple & $0 . \overline{-}$ & 1.46 & $\mathrm{~L}$ & 0.33 & 1.67 & $\mathrm{~L}$ & 0.00 & 0.00 & None & 0.33 & 1.67 & $\mathrm{~L}$ & 0.33 & 1.67 & $\mathrm{~L}$ \\
\hline Huawei & $0 . \overline{-}$ & 1.02 & $\mathrm{~L}$ & 0.00 & 0.00 & None & 0.33 & 1.67 & $\mathrm{~L}$ & 0.67 & 3.33 & M & 0.00 & 0.00 & None \\
\hline ZTE & $0 . \overline{-}$ & 0.94 & EL & 0.33 & 1.67 & $\mathrm{~L}$ & 0.67 & 3.33 & M & 0 & 0 & None & 0.33 & 1.67 & $\mathrm{~L}$ \\
\hline Samsung & 0.2 & -4.17 & & 0 & 0 & None & 0 & 0 & None & 0 & 0 & None & 0 & 0 & None \\
\hline LG & 0.24 & -5 & & 0 & 0 & None & 0 & 0 & none & 0 & 0 & none & 0 & 0 & None \\
\hline
\end{tabular}

\begin{tabular}{|c|c|c|c|c|c|c|c|c|}
\hline \multicolumn{6}{|c|}{ Changing working venue } & \multicolumn{6}{l|}{ Use of group transportation } & \multicolumn{3}{l|}{ Use of sustainable travel facilities } \\
\hline Index & Scale & Level & Index & Scale & Level & Index & Scale & Level \\
\hline 0.5 & 2.5 & M & 0.67 & 3.33 & H & 0.25 & 1.25 & L \\
\hline 0.5 & 2.5 & M & 0.33 & 1.67 & L & 0.5 & 2.5 & M \\
\hline 0 & 0 & None & 0 & 0 & None & 0.25 & 1.25 & L \\
\hline 0 & 0 & None & 0 & 0 & None & 0 & 0 & None \\
\hline 0.5 & 2.5 & M & 0 & 0 & None & 0 & 0 & None \\
\hline 0 & 0 & None & 0 & 0 & None & 0 & 0 & None \\
\hline
\end{tabular}

Shaded actions: better rank in comparison with all lower-ranked cases. None: action is not taken by the case.

APPENDIX 2: INDICES OF GHG 2 SUPPLY CHAIN MANAGEMENT ACTIONS

\begin{tabular}{|c|c|c|c|c|c|c|c|c|c|c|c|c|c|c|c|}
\hline \multirow[t]{2}{*}{ Corporation } & \multicolumn{3}{|c|}{ GHG 2} & \multicolumn{3}{|c|}{$\begin{array}{l}\text { Accreditation of } \\
\text { facilities }\end{array}$} & \multicolumn{3}{|c|}{$\begin{array}{c}\text { Reducing energy use } \\
\text { of facilities }\end{array}$} & \multicolumn{3}{|c|}{$\begin{array}{l}\text { Upgrading } \\
\text { facilities }\end{array}$} & \multicolumn{3}{|c|}{$\begin{array}{l}\text { Controlling energy } \\
\text { use of facilities }\end{array}$} \\
\hline & $\%$ & Scale & Level & Index & Scale & Level & Index & Scale & Level & Index & Scale & Level & Index & Scale & Level \\
\hline Apple & -0.07 & 1.46 & $\mathrm{~L}$ & 0 & 0 & None & 0.2 & 1 & $\overline{E L}$ & 0.5 & 2.5 & $\mathrm{M}$ & 0.14 & 0.71 & $\overline{E L}$ \\
\hline Nokia & -0.07 & 1.46 & $\mathrm{~L}$ & 0.5 & 2.5 & $\mathrm{M}$ & 0.2 & 1 & EL & 0 & 0 & None & 0.57 & 2.86 & $\mathrm{M}$ \\
\hline ZTE & -0.045 & 0.94 & EL & 0.5 & 2.5 & $\mathrm{M}$ & 0.2 & 1 & EL & 0 & 0 & None & 0.14 & 0.71 & EL \\
\hline Huwawei & -0.016 & 0.33 & EL & 0.5 & 2.5 & $\mathrm{M}$ & 0.4 & 2 & $\mathrm{~L}$ & 0 & 0 & None & 0.29 & 1.43 & $\mathrm{~L}$ \\
\hline LG & 0.09 & -1.875 & & 0 & 0 & None & 0.2 & 1 & EL & 0 & 0 & None & 0 & 0 & None \\
\hline Samsung & 0.24 & -5 & & 0 & 0 & None & 0.2 & 1 & EL & 0.5 & 2.5 & $\mathrm{M}$ & 0 & 0 & None \\
\hline
\end{tabular}

Shaded actions: better rank in comparison with all lower-ranked cases.

None: action is not taken by the case. 
APPENDIX 3: INDICES OF GHG 3 SUPPLY CHAIN MANAGEMENT ACTIONS

\begin{tabular}{|c|c|c|c|c|c|c|c|c|c|c|c|c|c|c|c|}
\hline \multirow{3}{*}{ Corporation } & \multirow{2}{*}{\multicolumn{3}{|c|}{ GHG 3}} & \multicolumn{6}{|c|}{ Suppliers relationship management } & \multicolumn{6}{|c|}{ Logistics } \\
\hline & & & & \multicolumn{3}{|c|}{ Auditing suppliers } & \multicolumn{3}{|c|}{ Helping suppliers } & \multicolumn{3}{|c|}{$\begin{array}{c}\text { Loading rate of } \\
\text { transportation facilities }\end{array}$} & \multicolumn{3}{|c|}{$\begin{array}{c}\begin{array}{c}\text { Transportation } \\
\text { mode }\end{array} \\
\end{array}$} \\
\hline & $\%$ & Index & Scale & Index & Scale & Index & Scale & Index & Scale & Index & Scale & Level & Index & Scale & Level \\
\hline Samsung & -0.14 & 0.50 & 2.50 & 0.5 & 2.5 & M & 0.2 & 1 & EL & 0 & 0 & None & 0.50 & 2.50 & $\mathrm{M}$ \\
\hline Nokia & -0.06 & 0.00 & 0.00 & 0 & 0 & none & 0 & 0 & none & 1 & 5 & $\mathrm{EH}$ & 1.00 & 5.00 & $\mathrm{EH}$ \\
\hline ZTE & -0.04 & 1.00 & 5.00 & 1 & 5 & EH & 0.2 & 1 & EL & 1 & 5 & $\mathrm{EH}$ & 0.00 & 0.00 & None \\
\hline LG & -0.02 & 0.00 & 0.00 & 0 & 0 & none & 0.4 & 2 & $\mathrm{~L}$ & 0 & 0 & None & 0.00 & 0.00 & None \\
\hline Huawei & 0.18 & 1.00 & 5.00 & 1 & 5 & $\mathrm{EH}$ & 0.6 & 3 & $\mathrm{M}$ & 0 & 0 & None & 0.00 & 0.00 & none \\
\hline
\end{tabular}

\begin{tabular}{|c|c|c|c|c|c|}
\hline \multicolumn{7}{|c|}{ Customer use } \\
\hline $\begin{array}{c}\text { Provide customers with } \\
\text { more efficient products }\end{array}$ & \multicolumn{2}{|c|}{ Educate customers } \\
\hline Index & Scale & Level & Index & Scale & Level \\
\hline 0.00 & 0.00 & None & 0.00 & 0.00 & None \\
\hline 0.00 & 0.00 & None & 1.00 & 5.00 & EH \\
\hline 0.00 & 0.00 & None & 0.00 & 0.00 & None \\
\hline 0.33 & 1.67 & L & 0.00 & 0.00 & None \\
\hline 0.00 & 0.00 & None & 0.00 & 0.00 & None \\
\hline
\end{tabular}

Shaded actions: Better rank in comparison with all lower-ranked cases.

None: The action is not taken by the case.

APPENDIX 4: RELATIVE GHG EMISSIONS ACROSS CASES

\begin{tabular}{|c|c|c|c|c|c|c|c|}
\hline \multicolumn{8}{|c|}{ GHG 1} \\
\hline$N$ & $\mathrm{AL}$ & A & $\mathrm{HL}$ & $\mathrm{H}$ & ZL & Z & $S L$ \\
\hline \multirow[t]{3}{*}{ Nokia } & Apple & Apple & Huawei & Huawei & ZTE & & Samsung \\
\hline & ZTE & & Samsung & & LG & & \\
\hline & Samsung & & LG & & & & \\
\hline$N-A L$ & $-30 \%$ & $\mathrm{~A}-\mathrm{HL}$ & $-15 \%$ & $H-Z L$ & $-18 \%$ & $Z-S L$ & $-26.7 \%$ \\
\hline \multicolumn{8}{|c|}{ GHG 2} \\
\hline A & NS & A & ZS & Z & HS & $\mathrm{H}$ & LS \\
\hline \multirow[t]{2}{*}{ Apple } & Nokia & Nokia & & ZTE & & Huawei & \\
\hline & Samsung & & Samsung & & Samsung & & Samsung \\
\hline$-7 \%$ & $+4 \%$ & $-7 \%$ & $+7 \%$ & $-4.7 \%$ & $+10.3 \%$ & $-2 \%$ & $+16.5 \%$ \\
\hline$A-N S$ & $-11 \%$ & $N-Z S$ & $-14 \%$ & $\mathrm{Z}-\mathrm{HS}$ & $-15 \%$ & $\mathrm{H}-\mathrm{LS}$ & $-18.5 \%$ \\
\hline \multicolumn{8}{|c|}{ GHG 3} \\
\hline$S$ & $\mathrm{NH}$ & $\mathrm{N}$ & $\mathrm{ZH}$ & Z & $\mathrm{LH}$ & L & $\mathrm{H}$ \\
\hline \multirow[t]{4}{*}{ Samsung } & Nokia & Nokia & & ZTE & & LG & \\
\hline & ZTE & & ZTE & & & & \\
\hline & LG & & LG & & LG & & \\
\hline & Huawei & & Huawei & & Huawei & & Huawei \\
\hline
\end{tabular}

